\title{
Mobilization of reserves and germination of seeds of Erythrina velutina Willd. (Leguminosae - Papilionoideae) under different osmotic potentials ${ }^{1}$
}

\author{
Renata Conduru Ribeiro Reis ${ }^{2,3 *}$, Bárbara França Dantas ${ }^{3}$, Claudinéia Regina Pelacani ${ }^{2}$
}

\begin{abstract}
Some environmental factors, including water availability, may influence seed germination. This study investigated the germination of E. velutina seeds submitted to different osmotic potentials and mobilization of reserves during water-stress. Scarified seeds were arranged in paper rolls and soaked in solutions of Polyethylene Glycol (PEG) prepared in osmotic potentials $0.0,-0.2,-0.4,-0.6$, and $-0.8 \mathrm{MPa}$ and kept into a seed germinator, at $25^{\circ} \mathrm{C}$, and $12 / 12 \mathrm{~h}$ photoperiod (L/D), during 10 days. The percentage, mean time, mean speed, germination speed index; as well as the germination uniformity coefficient were assessed. During germination process the total soluble sugars, reducing sugars, soluble protein, and total amino acids were quantified in the cotyledon, hypocotyl and radicle of soaked seeds and cotyledons of quiescent seeds (control). There was influence of osmotic potential on E. velutina seed germination. The germination percentage remained at high levels until -0.6 MPa and above this osmotic potential there has been no germination. The mobilization of stored reserves of carbon and nitrogen in E. velutina seeds was also influenced by water-stress. There was sensitiveness between -0.2 and $-0.6 \mathrm{MPa}$; however, the degradation and the mobilization of reserves was slower when the osmotic potential decreased.
\end{abstract}

Index terms: PEG 6000, water-stress, carbon of storage, soluble proteins, "mulungu", "caatinga".

\section{Mobilização de reservas e germinação de sementes de Erythrina velutina Willd. (Leguminosae - Papilionoideae) sob diferentes potenciais osmóticos}

\begin{abstract}
RESUMO - Alguns fatores ambientais podem influenciar a germinação, dentre eles a disponibilidade hídrica para as sementes. Este estudo investigou a germinação e a mobilização de reservas de sementes de E. velutina, submetidas a diferentes potenciais osmóticos. As sementes escarificadas foram embebidas em soluções de PEG preparadas em potenciais osmóticos de $0,0,-0,2,-0,4,-0,6$ e -0,8 $\mathrm{MPa}$, dispostas em rolos de papel e mantidas em germinador, a $25^{\circ} \mathrm{C}$ e fotoperíodo de $12 / 12 \mathrm{~h}(\mathrm{~L} / \mathrm{E})$, durante 10 dias. Foi avaliado: porcentagem, tempo médio, velocidade média e índice de velocidade de germinação; e coeficiente de uniformidade de germinação. Durante a germinação foram quantificados: açúcares solúveis totais, açúcares redutores, proteínas solúveis e aminoácidos totais nos cotilédones, no hipocótilo e na radícula das sementes embebidas e nos cotilédones de sementes quiescentes (controle). Houve influência do potencial osmótico na germinação de sementes de mulungu. A porcentagem de germinação permaneceu em níveis elevados até -0,6 $\mathrm{MPa}$; acima deste potencial não houve germinação. A mobilização de reservas de carbono e nitrogênio em sementes de $E$. velutina também foi influenciada pelo estresse hídrico. Houve sensibilidade entre -0,2 e -0,6 MPa, no entanto, a degradação e a mobilização de reservas foi mais lenta quando o potencial osmótico foi diminuído.
\end{abstract}

Termos para indexação: PEG 6000, estresse hídrico, carbono de reserva, proteínas solúveis, mulungu, caatinga.

\footnotetext{
${ }^{1}$ Submitted on $02 / 06 / 2012$. Accepted for publication on $08 / 13 / 2012$

${ }^{2}$ Departamento de Biologia, UEFS, 44036-900-Feira de Santana, Bahia, Brasil.
}

${ }^{3}$ Laboratório de Análise de Sementes - LASESA, Embrapa Semiárido, 56302-970-Petrolina, Pernambuco, Brasil.

*Corresponding author $<$ rconduru@gmail.com> 


\section{Introduction}

Drought is a frequent phenomenon and characteristic of Brazil, with variable intensity and effects in space and time. It is triggered by persistent lack of significant rainfall, where the spatial variability of precipitation makes the occurrence of this phenomenon more frequent.

As part of the Northeastern Semiarid Region of Brazil, the so called "Caatinga" is one of the largest Brazilian biomes, occupying circa $734,478 \mathrm{~km}^{2}$ (Silva et al., 2003). Within this region the climate, called "Droughts Polygon", is semiarid, hot, and with low annual precipitation (circa 250 $\mathrm{mm}$ to $800 \mathrm{~mm}$ ). Rainfall may vary, reaching until $1,000 \mathrm{~mm}$ year ${ }^{-1}$, in high precipitation years and $200 \mathrm{~mm}$ year-1 in years of drought (Maia, 2004). The Caatinga still presents elevated annual temperature mean $\left(28{ }^{\circ} \mathrm{C}\right)$ what causes intense evaporation (Araújo and Ferraz, 2003). In addition to these rigorous climatic conditions, the region is subjected to strong and dry winds; that contribute for aridity of landscape during drought months (Sampaio and Rodal, 2000).

With a large biological diversity and high levels of endemism, the northeaster semiarid region provides shelter to an ample range of species adapted to such type of climate. Many plants, especially perennial plants, adjust themselves to the periodicity of the climatic regimen by becoming deciduous plants during the dry period; being this a positive strategy adopted to avoid lost of water. Other plants adopt a different strategy to overcome the rigor of dry periods by concentrating their life cycle in the rainy period; what mainly occurs with therophyte bushes (Araújo and Ferraz, 2003). The knowledge level in relation to vegetative adaptation characteristics of plant species to Caatinga environmental conditions is significant; however, little is known about the adaptation mechanisms of seeds of these species under such conditions.

According to Nonogaki et al. (2010), the germination is a complex process in which the seed has to rapidly recuperate from the dryness from which has endured during the end of maturation process; and come back to a sustainable metabolism intensity that will provide essential cellular events to allow the emergence of the embryo, and be prepared for the subsequent growth of seedlings. The beginning of this process occurs by water absorption by the dry seeds until all matrixes, as well as all cellular contents, are fully hydrated.

Factors that interfere on seed germination of tropical arboreal species may be controlled genetically or controlled by environment. Among the factors controlled by environment, the most critical is lack of optimal conditions for seed germination and establishment of seedlings (Barbedo and Marcos-Filho, 1998). Khajeh-Hosseini et al. (2003) have stated that from the several environmental factors that are able to influence germination process, the water availability is one of the most important; what becomes more evident, when plants grown in regions with scarce rainfalls are considered.

Therefore, water availability is accounted as a limiting factor for starting the seed germination and establishment of seedling in the field; once it directly affects water relations within the seed and the subsequent development of seedlings, implying directly or indirectly in all remaining steps of plant metabolism, including reactivation of cellular cycle and growth (Castro et al., 2000).

For Larcher (2000), one of the most widely diffused methods for determining tolerance of a given plant to abiotic stress is observation of germination capacity of its seeds under the same conditions. Aiming at simulating standardized water-stress situations under laboratory conditions, germination studies have been performed by using of aqueous solutions of polyethylene glycol (PEG), for being a chemical compound inert and non-toxic (Murillo-Amador et al., 2002; Fanti and Perez, 2004).

Considering that quality of germination process is influenced by moisture conditions and that in available literature there is little information on use of polyethylene glycol 6000 (PEG-6000) and its effects on germination of E. velutina seeds; the aim of this study was to investigate the physiological and biochemical changes of seeds when subjected to different levels of osmotic potentials, induced by PEG 6000, during germination phase.

\section{Material and Methods}

Obtaining seeds: seeds of Erythrina velutina Willd. (Leguminosae-Papilionoideae), commonly known in Brazil as "mulungu', were obtained from matrixes-plants in district of "Jutaí", municipality of "Lagoa Grande", State of Pernambuco, Northeast Brazil (37 $17^{\circ} 03^{\prime \prime ~ S ~}$ latitude; $90^{\circ} 52^{\prime} 92^{\prime \prime} \mathrm{W}$ longitude) and were collected in October, 2009. These seed were manually processed, packaged into transparent plastic bags $(0.15 \mathrm{~mm}$ thick $)$ and then maintained under normal environmental conditions (temperature of $30 \pm 5{ }^{\circ} \mathrm{C}$; and $56 \pm 6 \% \mathrm{RH}$ ), in the Seed Analysis Laboratory of Embrapa Semiarid (LAESA), municipality of "Petrolina", State of Pernambuco, where the experiments were carried out during two months.

Germination test: previous to physiological test, a 
mechanical scarification of the external tegument was performed with the aid of a mini-grinding machine (Brand Western, Model R-40). Immediately after, scarified seeds were submitted to asepsis with a $2 \%$ commercial sodium hypochlorite solution, and then rinsed in sterile distilled water. After asepsis, seeds were evenly distributed on top of sheets of Germitest ${ }^{\mathbb{B}}$ paper, moistened with a PEG 6000 solution, at different osmotic potentials $(0.0,-0.2,-0.4,-0.6$, and $-0.8 \mathrm{MPa})$, prepared according to Villela et al. (1991), in a volume equivalent to 2.5 times the mass of dry substrate, and made into rolls. Then, the rolls were packaged into plastic bags and incubated into a germinator, at $25^{\circ} \mathrm{C}$, with a $12 / 12 \mathrm{~h}$ photoperiod (L/D), for 15 days. New sheets of paper Germitest ${ }^{\mathbb{B}}$, moistened with test fresh solutions were replaced at each two days interval, to allow exposing seeds to constant levels of osmotic potential of solutions and to avoid seed contamination by pathogens. Only seeds presenting radicle protrusion at least with $2 \mathrm{~mm}$ in length were considered germinated, and were daily counted. The variables assessed were: germination percentage; germination mean time; mean speed of germination; germination speed index, and germination uniformity coefficient (Santana and Ranal, 2004).

Recuperation germination test: at the end of period analyzed, seeds that did not germinate were rinsed in distilled water and distributed into roll of Germitest ${ }^{\circledR}$ paper, moistened with sterile distilled water at a volume corresponding to 2.5 times the mass of dry substrate, and then placed into a seed germinator, at $25^{\circ} \mathrm{C}$ and $12 / 12 \mathrm{~h}$ photoperiod (L/D), according to methodology adapted from Brasil (2009). Seeds considered germinated were those that had radicle protrusion of at least $2 \mathrm{~mm}$ long, which were counted daily. The variables assessed were: germination relative percentage and germination mean time (Santana and Ranal, 2004).

Extraction and analysis of reserves: scarified seeds of Erythrina velutina were subjected to three different osmotic potentials $(0.0,-0.2$, and $-0.6 \mathrm{MPa})$, inside rolls of Germitest ${ }^{\circledR}$ paper and maintained into seed germinator, at $25^{\circ} \mathrm{C}$ and $12 / 12 \mathrm{~h}$ photoperiod (L/D) during periods of 2 , 4,7 , and 10 days. At the end of such periods of imbibition, the cotyledons, aerial parts, and roots, as well as cotyledons of quiescent seeds, were collected and stored into a freezer, at $-20{ }^{\circ} \mathrm{C}$, until extraction moment. Simultaneously to this procedure, germination of seeds of each collection period was assessed.

Extraction of reserves was performed after homogenization of $0.5 \mathrm{~g}$ of samples collected into $5 \mathrm{~mL}$ of potassium phosphate buffer $(0.1 \mathrm{M} ; \mathrm{pH} 7.5)$ and centrifuged at $10,000 \mathrm{~g}$ during $20 \mathrm{~min}$., at $4{ }^{\circ} \mathrm{C}$. From the supernatant extract, the contents of soluble compounds were obtained with the aid of a spectrophotometer. Total soluble sugars (TSS) were determined by reaction with anthrone (Morris, 1948; Yemm and Willis, 1954) and reducing sugars (RS) were quantified by using 3,5 dinitrosalicylic acid (DNSA) for the oxidation of these compounds (Miller, 1959). Soluble proteins (SP) were determined according to methodology described by Bradford (1976); and the total amino acids (TAA) were quantified according to methodology proposed by (Rosen, 1957).

Experimental design and statistical analysis: a completely randomized experimental design was used for the experiment, which was composed of five osmotic potential treatments $(0.0,-0.2,-0.4,-0.6$, and $-0.8 \mathrm{MPa})$ and four replications of 25 seeds for each replication. Data on percentage of germination, germination time mean, germination speed mean, germination speed index, germination uniformity coefficient, and amount of reserves were analyzed by ANOVA, using statistical program Assistat (Silva and Azevedo, 2006). The differences among means obtained were compared by the Tukey test, at $5 \%$ probability. For performing ANOVA, data on percentage of germination were transformed by the function $(x+0 .)^{0.5}$; and the standard error of mean were also established.

\section{Results and Discussion}

Percentage germination remained in high levels until osmotic potential of $-0.6 \mathrm{MPa}$; above such level the germination process was inhibited in function of water restriction promoted.

However, when adequate conditions for germination were re-established the seeds subjected to osmotic potential of $-0.8 \mathrm{MPa}$ have had $100 \%$ germination. With this result it becomes evident that in such osmotic potential, the seeds have not lost their viability; and also have not entered the dormancy period. Such type of response comes to be important in species subjected to more severe water-stress conditions, where soon after environmental conditions are restored the seeds display a germination capacity still higher, when compared with seeds not submitted to waterstress conditions; thus allowing their survival and survival of the species. According to Bewley and Black (1994), under natural conditions, the water stress may act in a positive manner for the establishment of some plant species, causing a considerable delay in the germination time of seeds. 
This way, the germination is distributed in space and time, increasing probability of plants find adequate environmental conditions for their establishment and development.

The influence of water restriction imposed by osmotic potential from -0.2 to $-0.6 \mathrm{MPa}$ was more evident for seeds of the control treatment and, when the osmotic potential of solution was reduced, longer time was needed for seeds to swell and germinate; resulting in lower mean speed of germination. The best germination uniformity rate of seeds was obtained in osmotic potential of -0.2 MPa (Table 1). Rosa et al. (2005) have clearly presented the difficulty imposed by osmotic potential negative on germination of "Timbó" (Ateleia glazioviana Baill.) seeds, when starting from -0.4 MPa, there was a sharp increase in the accumulated germination along time; what was still more worsened when were used osmotic potentials of -0.6 and $-0.8 \mathrm{MPa}$. Within this study, similar results were found for the seeds of E. velutina.

Table 1. Percentage germination (G), mean time of germination (MT), germination speed mean (SM), germination speed index (GSI, radicle protrusion .day-1), and germination uniformity coefficient (GUC) of E. velutina seeds subjected to different levels of water stress (MPa) during germination.

\begin{tabular}{cccccl}
\hline Treatments $(\mathrm{MPa})$ & G $(\%)$ & MT (days) & SM $\left(\right.$ days $\left.{ }^{-1}\right)$ & GSI & GUC \\
\hline 0.0 & $100 \mathrm{a}^{*}$ & $4.43 \mathrm{c}^{*}$ & $0.23 \mathrm{a}^{*}$ & $2.49 \mathrm{a}^{*}$ & $0.78 \mathrm{bc}^{*}$ \\
-0.2 & $96 \mathrm{a}$ & $5.59 \mathrm{c}$ & $0.18 \mathrm{~b}$ & $1.77 \mathrm{~b}$ & $1.63 \mathrm{a}$ \\
-0.4 & $96 \mathrm{a}$ & $8.02 \mathrm{~b}$ & $0.12 \mathrm{c}$ & $1.27 \mathrm{bc}$ & $0.35 \mathrm{bc}$ \\
-0.6 & $96 \mathrm{a}$ & $11.77 \mathrm{a}$ & $0.08 \mathrm{c}$ & $0.83 \mathrm{c}$ & $0.95 \mathrm{ab}$ \\
\hline
\end{tabular}

*Means followed by the same letter in the columns do not statistically differ between each other by Tukey test, at $5 \%$ probability.

Different results have been found for seeds of the plant known in Brazil as "Canafístula" [Peltophorum dubium (Sprengel) Taubert], for which the limit of tolerance to waterstress was -1.4 MPa (Perez et al., 2001) and in seeds of Leucaena [Leucaena leucocephala (Lam.) de Wit] in which, although the seeds have had a negative response to the increase of waterstress, the germination of those seeds have occurred normally in all the osmotic potentials studied; including water-stress conditions of -1.2 MPa (Souza-Filho, 2006). Other authors have attributed significant reduction on seed germination with the reduction in levels of osmotic potential, to an insufficient diffusion of water through seed tegument (Fanti and Perez, 2003; Bakke et al., 2006).

The germination speed index (GSI) of E. velutina seeds was opposite to the increase in osmotic potential. Percentage of germination has presented reductions of circa $3.5 \%$, while the GSI was of $50 \%$, in the lower osmotic potential (-0.4 MPa) (Table 1). Such information, points out to GSI as one of the most sensitive factors to the effects of osmotic potential than the germination percentage (Marcos-Filho, 2005).

Mobilization of carbon and nitrogen reserves analyzed was influenced by water restriction in seeds of $E$. velutina. There was a decrease of TSS in the cotyledons of the seeds of all treatments, in relation to quiescent seeds. Water restriction sensitivity was observed in the osmotic potential of $-0.2 \mathrm{MPa}$, however, in the osmotic potential of $-0.6 \mathrm{MPa}$, the TSS degradation was even slower when compared to the other treatments assessed (Figure 1). An increase of osmotic potential, with a subsequent reduction, was also observed in levels of RS within two days; what might be related to smaller degradation of TSS under such condition (Figure 2).

The decrease of free-sugars observed during the radicle pre-protrusion period may have relation with initial seed metabolism activation, providing energy for seed germination before the initial processes of mobilization of reserves can occur (Pritchard et al., 2002).

As stated by Pontes et al. (2002), the use of starch or soluble sugars is variable and depends on plant species and occurs during germination, or during seedling stage. During mobilization of reserves in seeds of Apuleia leiocarpa (Vogel) J.F.Macbr. these same authors have not found statistically significant differences in content of soluble sugars along imbibition period.

Accumulation of TSS in seeds subjected to osmotic potentials of higher water-restriction may also be an attempt of osmotic adjustment, once soluble sugars have an important role in the osmotic adjustment, besides indirect protection effects such as in the stabilization of proteins (Carpenter et al., 1990; Bianchi et al., 1991). Among the soluble sugars, the sucrose is one of the most accumulated in seeds and plays important role in the tolerance to cellular desiccation (Hincha et al., 2006). 

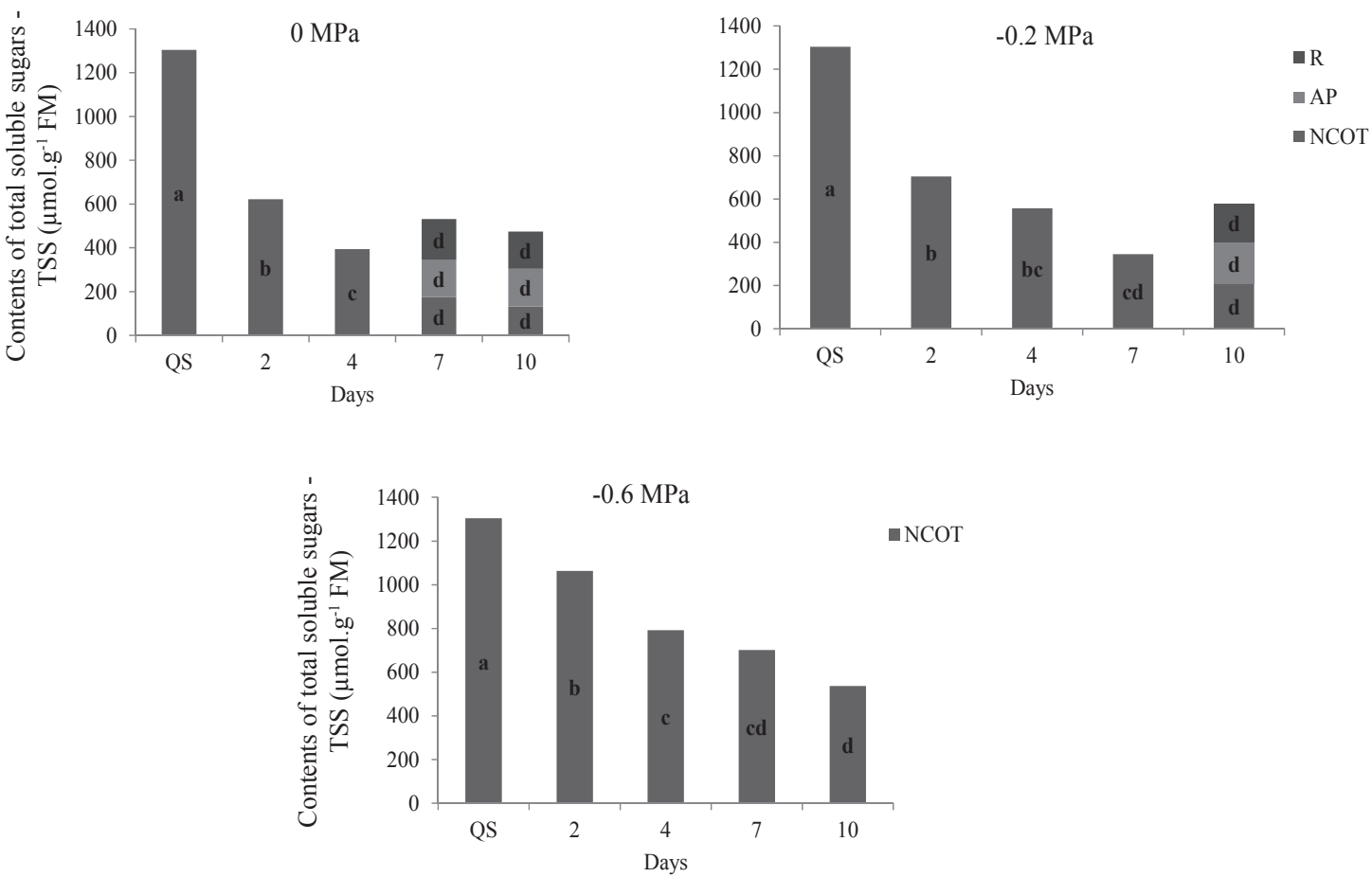

Figure 1. Content of total soluble sugars - TSS ( $\mu$ mol.g-1 FM) in cotyledons of quiescent seeds (QS) and in cotyledons of normal seeds (NCOT), aerial parts (AP), and radicle (R) of seeds of E. velutina subjected to different levels of water stress $(\mathrm{MPa})$, during germination.
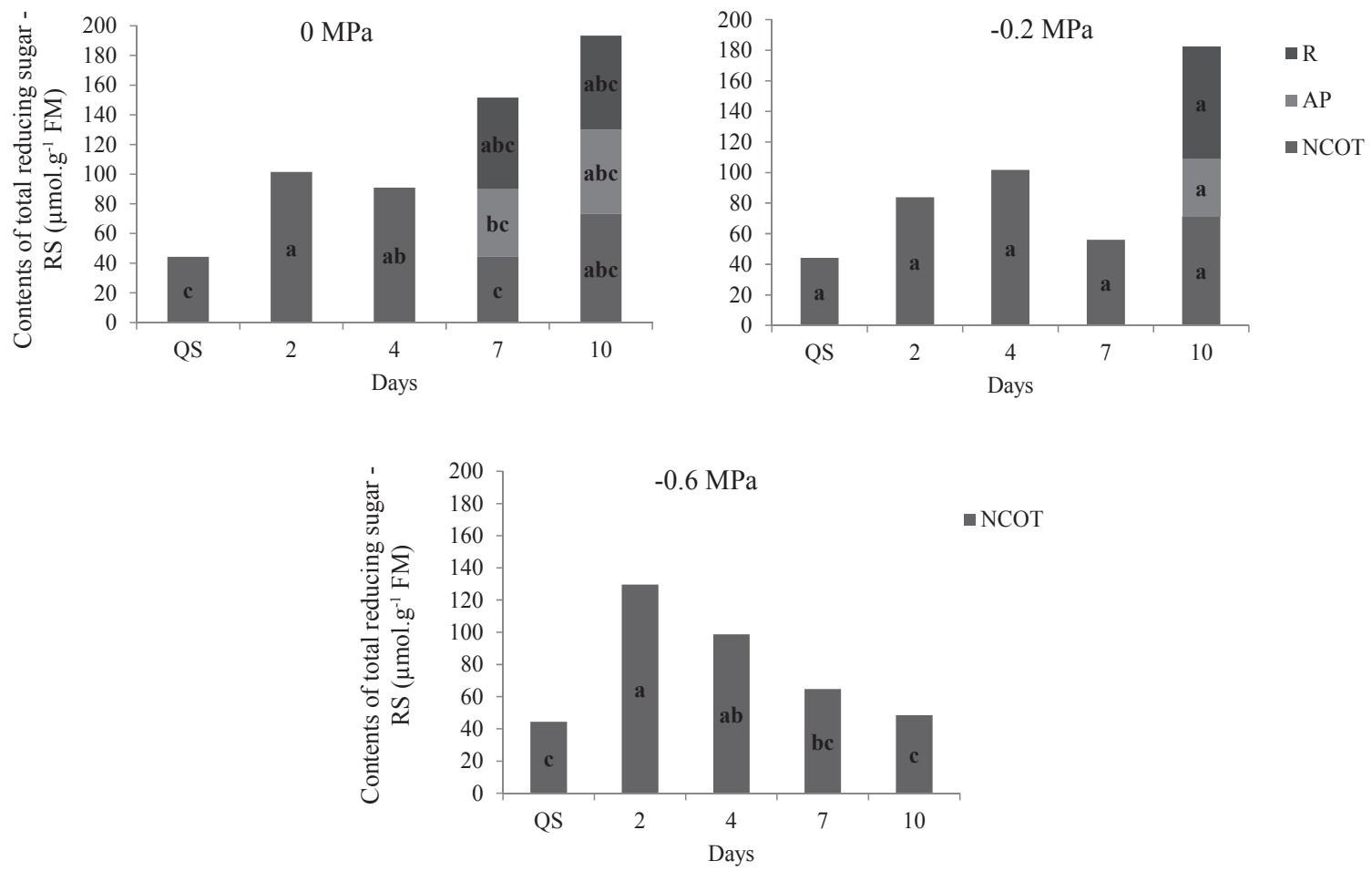

Figure 2. Content of total reducing sugars - RS ( $\mu$ mol.g $\left.\mathrm{g}^{-1} \mathrm{FM}\right)$ in cotyledons of quiescent seeds $(\mathrm{QS})$ and in cotyledons of normal seeds (NCOT), aerial parts (AP), and radicle (R) of seeds of E. velutina subjected to different levels of water stress $(\mathrm{MPa})$, during germination. 
In studies of carbohydrates reserve composition, Mello et al. (2010) have found that in seeds of Erythrina speciosa Andr., sucrose was not the main accumulated sugar. However, the same authors have observed high quantities of oligosaccharides of the raffinose $\left(\mathrm{C}_{18} \mathrm{H}_{32} \mathrm{O}_{16}\right)$ family, associated to tolerance to desiccation. Similar results were found by Mayworm et al. (1998) in E. velutina seeds. Results found by these authors, jointly with high ratios of unsaturated fatty acids, suggest that sugars and lipids could play an important role in the movement of water within the plant, thus protecting the embryonic cell membranes against injuries cause during desiccation.

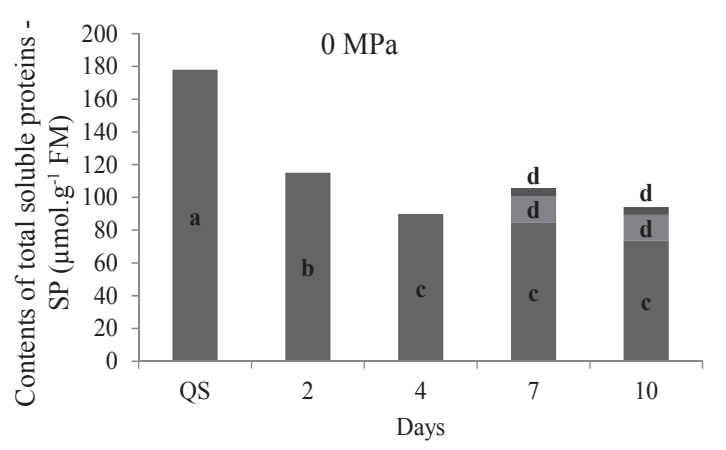

Mean contents of SP and TAA in E. velutina seeds were influenced by the osmotic potential and also by imbibition time (Figures 3 and 4, respectively). In osmotic potentials of 0 and $-0.2 \mathrm{MPa}$, contents of proteins underwent reduction during the initial imbibition periods assessed ( 2 and 4 days) in relation to seeds with quiescent cotyledons. Values of SP have remained equal during pre-germination period and radicle post-protrusion for the same osmotic potentials ( 0.0 and -0.2 $\mathrm{MPa}$ ), although with a decreasing trend (Figure 3). In control treatment and in osmotic potential of $-02 \mathrm{MPa}$, contents of TAA in the cotyledons, aerial parts, and roots varied according to the rates of proteins mobilization (Figure 4).

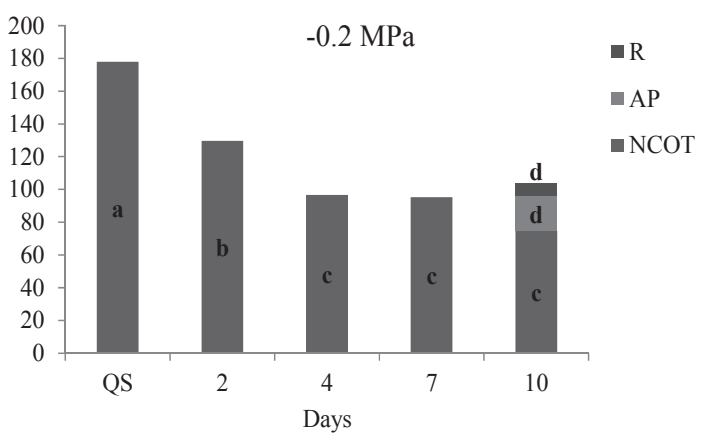

$-0.6 \mathrm{MPa}$

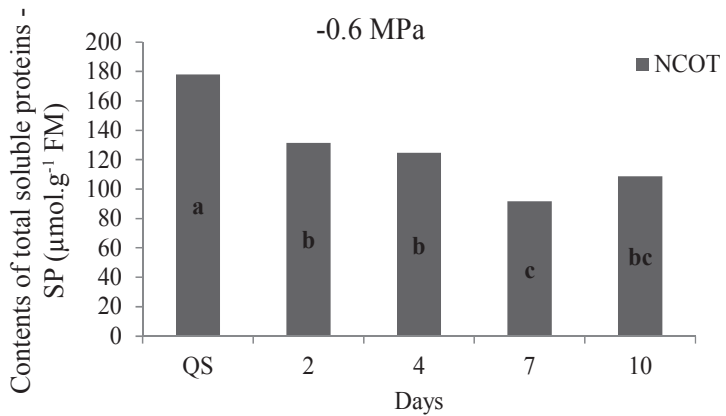

Figure 3. Content of soluble proteins - SP $\left(\mu \mathrm{mol} . \mathrm{g}^{-1} \mathrm{FM}\right)$ in cotyledons of quiescent seeds (QS) and in cotyledons of normal seeds (NCOT), aerial parts (AP), and radicle (R) of seeds of E. velutina subjected to different levels of water stress $(\mathrm{MPa})$, during germination.

According to Bewley and Black (1994), proteins are mobilized during germination and the subsequent growth of seedlings. Such results also agree with those obtained by Müntz et al. (2001), in which the mobilization of proteins stored in cotyledons are only detectable after radicle protrusion. As stated by Corte et al. (2006), in seeds of "Sibipiruna" (Caesalpinia peltophoroides Benth.) the content of proteins decreased only after radicle protrusion and growth of seedlings. As for seeds of Milk Weed (Euphorbia heterophylla L.), as well as for seeds of E. velutina, the proteins were continuously degraded soon after beginning of imbibition period (Suda and Giorgini, 2000).

Mobilization of SP and TAA were reduced in seeds subjected to osmotic potentials of - $0.6 \mathrm{MPa}$ until the imbibition period under study (10 days) (Figures 3 and 4, respectively). These results may be partially explained by possibility of inhibition of proteases activity in the cotyledons and the translocation their products (amino acids) to the embryonic axis of seeds of $E$. velutina, as consequence of higher waterrestriction provided by the osmotic potential of PEG solution. 


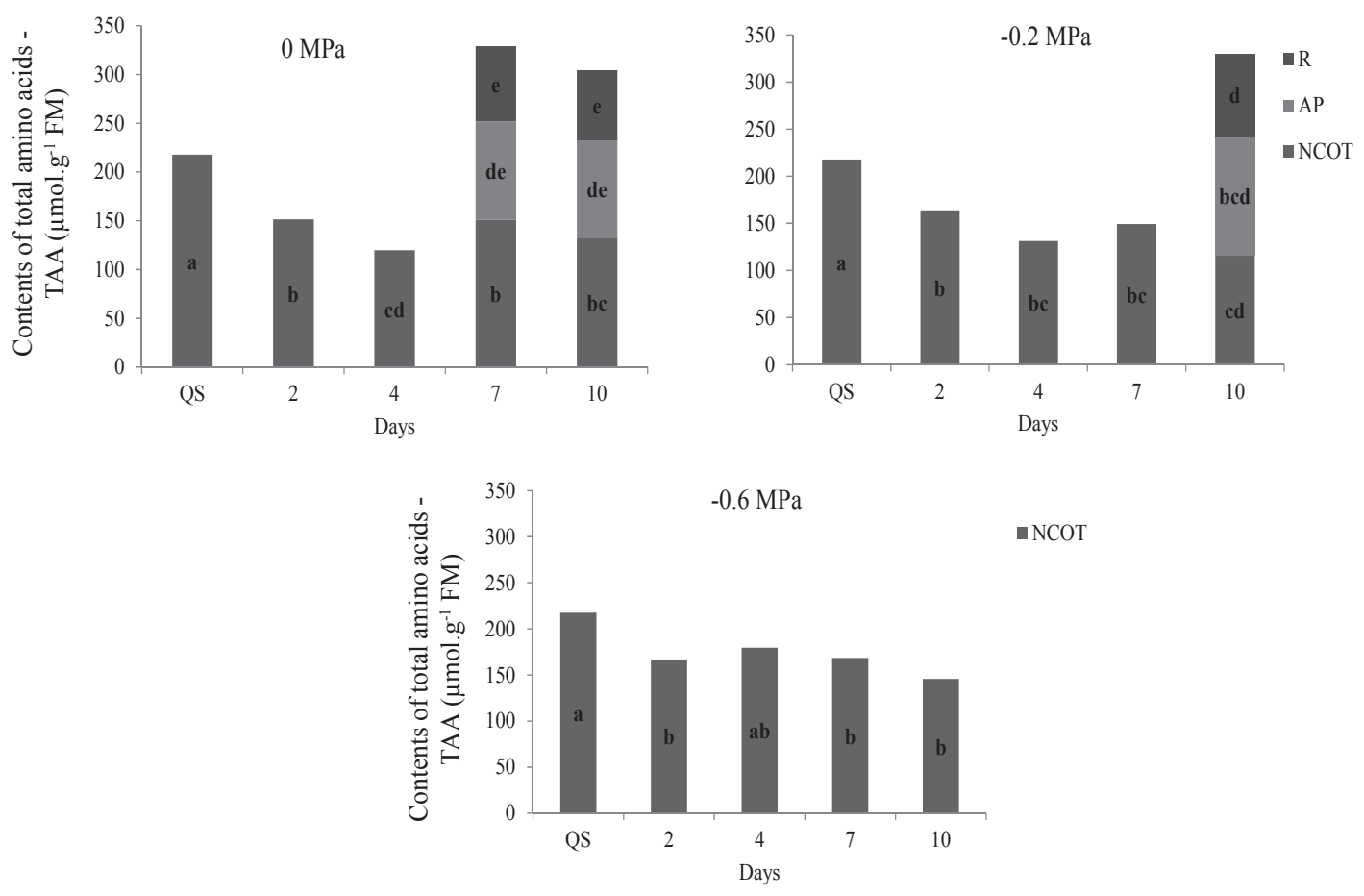

Figure 4. Content of total amino acids - TAA ( $\mu$ mol.g $\left.{ }^{-1} \mathrm{FM}\right)$ in cotyledons of quiescent seeds $(\mathrm{QS})$ and in cotyledons of normal seeds (NCOT), aerial parts (AP), and radicle (R) of seeds of $E$. velutina subjected to different levels of water stress $(\mathrm{MPa})$, during germination.

Water is responsible for re-hydration of seeds through absorption and is directly or indirectly involved in all steps of their subsequent metabolism. Its participation is decisive on enzymatic reactions, as solvent and transporter of metabolites, and as reagent in the hydrolytic digestion of proteins, carbohydrates, and lipids of the reserve tissues of seeds (Carvalho and Nakagawa, 2000).

Water-deficit imposes an elongation of the embryonic phase of the imbibition process due to reduction in the enzymatic activity and consequently to a smaller meristematic development and delay in radicle protrusion (Falleri, 1994); as has occurred for seeds of E. velutina subjected to osmotic potential of $-0.2 \mathrm{MPa}$ (and mainly found in osmotic potential of $-0.6 \mathrm{MPa}$ ). Seed vigor is more sensitive to water-deficit than rate of germination of E. velutina seeds.

\section{Conclusions}

Water-stress affects germination of Erythrina velutina seeds.

The maximum limit of tolerance of seeds of the species Erythrina velutina, to water-restriction is the osmotic potential of $-0.6 \mathrm{MPa}$.
The processes of mobilization and degradation of seed reserves are totally influenced by water restriction.

Seeds of Erythrina velutina pose a differentiated behavior in relation to performance of viability and vigor when subjected to different levels of water stresses simulated by Polyethylene glycol.

\section{Acknowledgements}

The first author would like to thank to "CAPES" for the financial support granted to carry out this study.

\section{References}

ARAÚJO, E.L.; FERRAZ, E.M.N. Processos ecológicos mantedores da diversidade vegetal na caatinga: estado atual do conhecimento. In: CLAUDINO, S.V. (Org.), Ecossistemas brasileiros: manejos e conservação. Fortaleza: Expressão Gráfica, Fortaleza, p.115-128, 2003.

BARBEDO, C.J.; MARCOS-FILHO, J. Tolerância à dessecação em sementes. Acta Botanica Brasilica, v.12, n.2, p.113-204, 1998.

BAKKE, I.A; FREIRE, A.L.O.; BAKKE, O.A.; ANDRADE, A.P.; BRUNO, R.L.A. Water and sodium chloride effects on Mimosa tenuiflora (Willd.) Poiret seed germination. Revista Caatinga, v.19, n.3, p.261-267, 
2006. http://periodicos.ufersa.edu.br/revistas/index.php/sistema/article/ view/82/50

BEWLEY, J.D.; BLACK, M. Seeds: physiology of development and germination. New York and London: Plenum Press, 1994. 445p.

BIANCHI, G.; GAMBA, A.; MURELli, C.; SALAMINI, F.; BARTELS.; D. Novel carbohydrate metabolism in the resurrection plant Craterostigma plantagineum. The Plant Journal, v.1, p.355-359, 1991.

BRADFORD, M.M. A rapid and sensitive method for the quantitation of microgram quantities of protein utilizing the principle of protein-dye binding. Analytical Biochemistry, v.72, n.1/2, p.248-254, 1976.

BRASIL. Ministério da Agricultura, Pecuária e Abastecimento. Regras para análise de sementes. Ministério da Agricultura, Pecuária e Abastecimento. Secretaria de Defesa Agropecuária. Brasília: MAPA/ACS, 2009. 395p. http://www.agricultura.gov.br/arq_editor/file/laborat\%c3\%b3rio/ sementes/regras $\% 20$ para $\% 20$ analise $\% 20$ de $\% 20$ sementes.pdf

CARPENTER, J.F.; CROWE, J.H.; ARAKAWA. T. Comparison of solute-induced protein stabilization in aqueous solution and in the frozen and dried states. Journal of Dairy Science, v.73, p.3627-3636, 1990.

CARVALHO, N.M.; NAKAGAWA, J. Sementes: ciência, tecnologia e produção. 4.ed. Jaboticabal: FUNEP, 2000. 588p.

CORTE, B.V.; BORGES, E.E.L.; PONTES, C.A.; LEITE, I.T.A.; ENTRELLA, M.C.; MATHIAS, A.A. Mobilização de reservas durante a germinação das sementes e crescimento das plântulas de Caesalpinia peltophoroides Benth. (Leguminosae Caesalpinoideae). Revista Árvore, v.30, n.6, p.941-949, nov./dez. 2006. http://www.scielo.br/scielo.php?pid=s010067622006000600009\&script=sci_arttext

CASTRO, R.D.; VAN LAMMEREN, A.A.M.; GROOT, S.P.C.; BINO, R.J.; HILHORST, H.W.M. Cell division and subsequent radicle protrusion in tomato seeds are inhibited by osmotic stress but DNA synthesis and formation of microtubular cytoskeleton are not. Plant Physiology, v.122, p.327-335, 2000. http://www.plantphysiol.org/content/122/2/327.full.pdf

FALLERI, E. Effect of water stress on germination in six provenances of Pinus pinaster Ait. Seed Science and Technology, v.22, n.3, p.591-599, 1994.

FANTI, S.C.; PEREZ, S.C.J.G.A. Efeito do estresse hídrico e envelhecimento precoce na viabilidade de sementes osmocondicionadas de paineira (Chorisia speciosa). Pesquisa Agropecuária Brasileira, v.38, n.4, p.537-543. 2003. http://www.scielo.br/scielo.php?pid=s0100204x2003000400013\&script=sci_arttext

FANTI, S.C.; PEREZ, S.C.J.G.A. Processo germinativo de sementes de painera sob estresses hídrico e salino. Pesquisa Agropecuária Brasileira, v.39, n.9, p.903-909, 2004. http://www.scielo.br/scielo.php?script=sci arttext\&pid=s0100-204x2004000900010

HINCHA, D.K.; POPOVA, A.V.; CACELA, C. Effects of sugars on the stability of lipids membranes during drying, In: Liu, L. (Ed.), Advances in Planar Lipid Bilayers and Liposomes. v.3, p.189-217, 2006.
KHAJEH-HOSSEINI, M.; POWELL, A.A.; BINGHAM, I.J. The interaction between salinity stress and seed vigour during germination of soybean seeds. Seed Science and Technology, v.31, p.715-725. 2003.

LARCHER, W. Ecofisiologia vegetal. São Carlos: RIMA. 2000. 531p.

MAIA, G.N. Caatinga: árvores e arbustos e suas utilidades. São Paulo. Editora D \& Z, 2004. 413p.

MARCOS-FILHO, J. Fisiologia de sementes de plantas cultivadas. Piracicaba: FEALQ, 2005. 495p.

MAYWORM, M.A.S.; NASCIMENTO, A.S.; SALATINO, A. Seeds of species from the "caatinga": proteins, oils and fatty acid contents. Revista Brasileira de Botânica, v.21, p.961-972, 1998. http://www.scielo.br/ scielo.php?script=sciarttext\&pid=s0100-84041998000300009

MELLO, J.I.O.; BARBEDO, C.J.; SALATINO, A.; FIGUEIREDORIBEIRO, R.C.L. Reserve carbohydrates and lipids from the seeds of four tropical tree species with different sensitivity to desiccation. Brazilian Archives of Biology and Technology, v.53, n.4, p.889-899, 2010. http://www. scielo.br/scielo.php?pid=s1516-89132010000400019\&script=sci_arttext

MILLER, G.L. Use of dinitrosalicilic acid reagent for determination of reducing sugar. Analytical Chemistry, v.31, p.426-428, 1959.

MORRIS, D.L. Quantitative determination of carbohydrates with Drywood's anthrone reagent. Science, v.107, p.254-255, 1948.

MÜNTZ, K.; BELOZERSKY, M.A; DUNAEVSKY, Y.E; SCHLERETH, A.; TIEDEMANN, J. Stored proteinases and the initiation of storage protein mobilization in seeds during germination and seedling growth. Journal of Experimental Botany, v.52, n.362, p.1741-1752, 2001. http:// jxb.oxfordjournals.org/content/52/362/1741.full.pdf + html

MURILLO-AMADOR, B.; LOPEZ-AGUILAR, R.; KAYA， C.; LARRINAGA MAYORAL, J.; FLORES-HERNANDEZ, A. Comparative effects of $\mathrm{NaCl}$ and polyethylene glycol on germination, emergence and seedling growth of cowpea. Journal Agronomy and Crop Science, v.188, p.235-247, 2002.

NONOGAKI, H.; BASSEL, G.W.; BEWLEY, J.D. Germination-still a mystery. Plant Science, v.179, n.6, p.574-581, 2010.

PEREZ, S.C.J.G.A.; FANTI, S.C.; CASALI, C.A. Influência da luz na germinação de sementes de canafístula submetidas ao estresse hídrico. Bragantia, v.3, n.60, p.155-166, 2001. http://www.scielo.br/pdf/brag/ v60n3/a02v60n3.pdf

PONTES, C.A.; BORGES, E.E.L.; SOARES, C.P.B. Mobilização de reservas em sementes de Apuleia leiocarpa (Vogel) J.F. Macbr. (garapa) durante a embebição. Revista Árvore, v.26, n.5, p.593-601, 2002. http:// www.scielo.br/pdf/rarv/v26n5/a10v26n5.pdf

PRITCHARD, S.L.; CHARLTON, W.L.; BAKER, A.; GRAHAM, I.A. Germination and storage reserve mobilization are regulated independently in Arabidopsis. The Plant Journal, v.31, n.5, p.639-647, 2002. 
ROSA, L.S.; FELIPPI, M.; NOGUEIRA, A.C.; GROSSI, F. Avaliação da germinação sob diferentes potenciais osmóticos e caracterização morfológica da semente e plântula de Ateleia glazioviana Baill (timbó). Cerne, v.11, n.3, p.306-314, jul./set., 2005. http://www.dcf.ufla.br/cerne/ artigos/11-02-20093237v11n3artigo\%2009.pdf

ROSEN, H. A modified ninhydrin calorimetric analysis for amino acids. Archives of Biochemistry and Biophysics, v.67, p.10-15, 1957.

SAMPAIO, E.V.S.B.; RODAL, M.J. Fitofisionomias da caatinga. Avaliação e identificação de ações prioritárias para a conservação, utilização sustentável e repartição de benefícios da biodiversidade do bioma caatinga. In: WORKSHOP BIODIVERSIDADE DA CAATINGA, Petrolina, Pernambuco, p.49-50, 2000.

SANTANA, D.G.; RANAL, M.A. Análise da germinação: um enfoque estatístico. Brasília: Editora Universidade de Brasília, 2004, 248p.

SILVA, F.A.S.E.; AZEVEDO, C.A.V. A New Version of The Assistant-Statistical Assistance Software. In: WORLD CONGRESS ON COMPUTERS IN AGRICULTURE, 4., Orlando-FL-USA: Anais... Orlando: American Society of Agricultural and Biological Engineers, p.393-396, 2006.

SILVA, J.M.C.; TABARELLI, M.; FONSECA, M. T.; LINS, L.V. (Orgs.). Biodiversidade da caatinga: áreas e ações prioritárias para a conservação. Brasília, DF: Ministério do Meio Ambiente: Universidade Federal de Pernambuco, 2003. p.382.
SOUZA FILHO, A.P.S. Influência da temperatura, luz e estresses osmótico e salino na germinação de sementes de Leucaena leucocephala. Pasturas Tropicales, v.22, n.2, p.47-53, 2006. http://ciat-library.ciat. cgiar.org/articulosciat/past2225.pdf

SUDA, C.N.K.; GIORGINI, J.F. Seed reserve composition and mobilization during germination and initial seedling development of Euphorbia heterophylla. Revista Brasileira de Fisiologia Vegetal, v.12, n.3, p.226-245, 2000. http://www.scielo.br/pdf/rbfv/v12n3/9356.pdf

VILLELA, F.A.; DONI FILHO, L.; SEQUEIRA, E.L. Tabela de potencial osmótico em função da concentração de polietilenoglicol 6000 e da temperatura. Pesquisa Agropecuária Brasileira, v.26, n.11/12, p.1957-1968, nov./dez. 1991. http://webnotes.sct.embrapa.br/pdf/pab1991/novdez/pab18novdez91.pdf

YEMM,E.W.; WILLIS,A.J. The estimation of carbohydrates in plants extracts by anthrone. Biochemical Journal, v.57, p.508-514, 1954. http://www.ncbi. nlm.nih.gov/pmc/articles/pmc1269789/pdf/biochemj01083-0159.pdf 